\title{
Criteria for Selecting College Students
}

(Entrance Requirements Again)

GEORGE E. CARROTHERS

\begin{abstract}
Director, Bureau of Co-operation with Educational Institutions, University of Michigan
\end{abstract}

W HILE considering the topic, the Need for Institutions of Higher Education to Examine their Programs, it should be suggested that the secondary schools be urged to examine their programs and to plan to meet varied needs of all youth in their communities without demanding special attention to the preparation of the one seventh of their pupils who later enter college. Fifty years ago the academies and secondary schools enrolled less than 400,000 pupils-three or four per cent of teen-age youth. It was not difficult in those days for teachers to select and train pupils so that success in college was almost guaranteed. Students who did not do well in high school or college were dropped out. The country was young, jobs were plentiful, and education was neither thought of as necessary for all nor as the privilege of all. The past half century has seen great changes. Secondary schools of today enroll $7,000,000$ pupils, three fourths of all teen-age youth, and they have such a comprehensive task to meet that it behooves colleges not to hinder but to help them. College faculties, awake to the situation and not too deeply steeped in the former college-prep-school tradition, are making a serious attempt to get off the backs of the over-burdened secondary schools. Educational institutions at each level ought to be permitted to be autonomous.

\section{CHANGED ENROLLMENTS AND CHANGED OBJECTIVES}

We have moved from a time when three to five per cent of teen-age youth were going to secondary schools to a time when seventy-five to ninety per cent are attending these schools; from a time when pupils were highly selected to a time when parents think that all youth should have at least a high-school education; from a time when only a few boys were attending these schools to a time when all boys and all girls with widely varying abilities and interests are on the way to the local high school, of which there are approximately 30,000 in this country; from a time when the secondary school was primarily a college preparatory school to a time when the chief business of the secondary school is to bring the largest amount of satisfartory personal development to the greatest number of $\mathrm{ALL}$ youth within its community; from a time when nearly 100 per cent of the "prep" school graduates went to college to a time when only fifteen to sixteen per cent are entering traditional colleges and universities. All of these and many cther considerations make it imperative that institutions of higher education cease thinking of the secondary school as primarily designed to prepare students $f_{\text {or }}$ college. The following quotation formerly carried in the publications of 
a great university and dropped a decade ago as being out of place in the literature or thinking of forward-looking, twentieth century colleges is indicative of conditions once existing. The college stated that the principal of the high school should recommend only those graduates "whose character, scholarship interests, and attainments, seriousness of purpose and intellectual promise are so clearly superior that the school is willing to stand sponsor for their success at the University." What an easy time a university faculty was planning for itself when it asked for only those high-school graduates which the local school would guarantee to succeed in college! High schools today are concerned with all of their students, eighty-five per cent of whom are not looking toward colleges for further education; these schocls should be encouraged to do their whole job well.

\section{PROPOSED ENTRANCE CRITERIA}

It is proposed that institutions of higher education give consideration to some needed changes in their entrance requirements in the light of changed conditions. Why not forget specific majors and minors taken in high school; why not abolish the recommendation of the high-school principal which frequently puts him "on the spot," and set up Criteria of Selection suited to the purposes of each institution concerned? As a school administrator, it has always seemed best to me to adopt certain criteria of selection when looking for teachers, secretaries, and clerks. Instead of refusing to talk with an applicant for a position unless she has had a certain number of units of English in high school or college, so many units in mathematics, language, history, and other subjects, it has been found a good practice to decide on the qualifications desired for the position, than to interview all comers and evaluate them with the measuring rods agreed upon. Nor has the writer felt it appropriate to blame colleges and training schools for lack of success of the persons chosen. He has profited more by blaming himself for: (1) not being able to make a good selection, and (2) not being able to get the person to succeed after selection has been made. With this idea in mind, the following criteria are proposed for the selection of college students. And it is hoped that these will be thought of as a means to get certain capable students into college rather than a set of "requirements" for keeping certain others out.

1. Interest in the type of educational experience which the particular college seems to be able to offer.

2. Maturity: a certain degree of mental, social, physical maturity.

3. Health: this is of great importance to every college student.

4. Knowledge in certain important major fields.

5. Skills, without which no student can hope for success.

6. Competence, of special kinds to be demanded by certain specialized types of colleges or professional schools.

7. Ability, chiefly intellectual, which may be definitely indicated by a success- 
ful meeting of the first six items, or by additional tests and measurements.

\section{Interest}

It is not expected that great interest in higher education will be shown by the student when he seeks entrance to college, yet it is believed that at least a little interest beyond that of parental aspiration, compulsion, fraternity or sorority glamour, or desire to get away from home should be manifest. The admissions officer can and should make an attempt through the use of aptitude tests and personal interviews to discover the particular field or area of interest. Why, for example, should a young man who made a poor record in high school in both science and mathematics and who declares that he is not interested in these subjects, be accepted by a college of engineering as a freshman even though his widowed mother does state that she will pay the student's college expense only if he enters engineering, the course his father had always wanted to pursue! The young man liked to read history and English, and even in high school he had done some acceptable writing. His failure in engineering was a foregone conclusion. Interest in further education of the kind a particular college can offer is important.

\section{Maturity}

We must not return to a time when secondary schools and colleges compete for the same students, the suggestion of the Educational Policies Commission and practices of admissions officers in hard-pressed colleges to the contrary notwithstanding. Most preparatory schools as adjuncts to colleges have disappeared, and all should disappear. Colleges have a right to expect that degree of maturity which usually comes to a youth who has lived with some satisfaction through his fourteenth to eighteenth years and has carried successfully a four-year high-school program consisting not only of academic and nonacademic subjects but a judicious number of so-called extra activities. Since many college failures can be traced to immaturity, social, physical, and mental, it is believed that this criterion is worthy of thoughtful consideration.

\section{Health}

Army experience has shown that an unusually large number of the young men of this country are physically fit; probably a larger percentage than would be found in any otner nation. Yet it has also been shown that several hundred thousand young men were not in that state of physical and mental fitness which they might have had if more adequate attention had been given to health. Some colleges and universities do consider the health of students after they have entered, and all institutions of higher education should thus meet student needs. A matter of the greatest importance is that of giving attention to health at the time of the selection of the student. Some students enter college in such poor health that the ensuing experience is not satisfac- 
tory either to them or to the college. The best school systems require health examinations of applicants for positions as teachers and secretaries; is it not as important to require health examinations of prospective college students?

\section{Knowledge}

The writer suggests the abolishing of all requirements of a certain number of units to be earned in high school. Many colleges state that a prospective student must have had three units or years of English in the preparatory school, three years of mathematics, two years of a foreign language, two years of history or social studies, two years of science, or some combination of these. Yet it is known that two years of Latin in one school is not at all the same as two years of Latin in another school. The writer has visited schools in which pupils have learned a great deal more Latin and have acquired a vastly better discipline during one year of study of that subject than in two years or even in three years in other schools. Tests given many times and in many schools to thousands of students show clearly that the sophomores in some schools know more in the field of English than seniors in other schools. Admissions officers know that a " $B$ " average from some schools is no better than a "C" average from others. Why then should colleges compel high schools to hold pupils two or three years in certain courses merely to satisfy college entrance requirements?

A report from Michigan State College is to the effect that certain areas of their college program are being placed on the accomplishment basis rather than on the time-served basis. In that college, 1,400 students were ready to enroll in a scheduled English program from which they were to gain a certain knowledge of English. A comprehensive examination was prepared. Factual data on the students were assembled. One hundred sixty-nine were considered ready and were permitted to take the examination. One hundred twenty-two passed with satisfactory marks and were given full credit for the work. Colleges should encourage high schools to place much of their work on the achievement basis rather than the time-served basis. Colleges should also state the level of achievement or accomplishment which will be expected in such fields as English, mathematics, and science, and they should help inigh schools to develop satisfactory means and measures for different stages of accomplishment.

In the course of visiting schools and counseling with teachers and administrators, it sometimes seems well to give brief tests to pupils. The writer is usually surprised at the results; so are the teachers. Pupils are frequently discovered who know English as well as college students; others who are hardly as well prepared as they should have been in the sixth or seventh grade. In scme schools it is discovered that embryo scientists and mathematicians are still being compelled to sit through dreary classes day after day so that the school can honestly state, that a particular pupil had "algebra 
40 minutes each day, five days each week, for 36 weeks." The Carnegie unit has been useful, but it is high time that it be given much less emphasis. Permit high-school staffs to place pupils in the subjects and courses which appear to be the most useful to the boys and girls enrolled in that school; then encourage both pupils and teachers to expect good performance or accomplishment. Let's help both high schools and colleges so to plan their work that recognition is given to accomplishment, rather than to hours spent in classrooms.

A powerful incentive to individual self-learning is provided when a school shifts emphasis from time-spent-in-the-classroom to accomplishment by the student. For example, the writer's interests in high school were so completely absorbed in the fields of science and mathematics that some other fields of knowledge were sadly neglected. On advice of the high-school principal he enrolled in a sub-freshman, non-credit course in English on entering Indiana University, for which he had to pay a rather substantial fee. There was probably no doubt in Professor Morton's mind about his needing that course. The instructor informed all of the students, however that passing the course and getting into freshman college English would depend not on the time spent in his classes but on what each student did. The fee paid and the knowledge of English were both important to the writer. After only a few weeks the comprehensive examination, set up as the final in the course, was passed; the fee returned; and the writer permitted to take college English. Skills

There are certain skills without which it is hardly possible to continue one's education. Skill in reading with understanding is of first importance. President E. C. Elliott of Purdue University more than two decades ago related his experience with an applicant for admission, which furnishes a good illustration at this point. The young man admitted that he had "flunked" out of freshman classes in two other colleges of engineering, but he wanted to be an engineer. President Elliott asked the would-be student to read several pages in a physics book and then to tell what he had read. After several attempts, the student confessed that he did not know what the chapter said. Finally, Dr. Elliott sat down with the young man and taught him line by line, even word by word, what the first paragraph meant. The student read the paragraph, and then told the University President what it said. He then asked: "Why in hell didn't someone teach me to read before this?"

In other places it has been pointed out that high schools are failing to teach pupils to. read even though requiring three or four years of sitting in English classes. ${ }^{1}$ Locking tc colleges for guidance instead of doing their own thinking, many high-school principals are requiring certain numbers of years

${ }^{1}$ Reading in Secondary Schools. Bulletin of the National Association of Secondary-School Principals. January, 1944. Pp. $83-88$. 
of traditional English, social studies, language, mathematics, science, and other subjects. If the college faculties could only bring themselves to the realization that they have adequate techniques for determining the skills which college students shculd possess, and should then tell administrators in secondary schools that they are not specially interested in numbers of units in the different subjects; that they will expect a certain ability or skill in the use of mathematics and in other areas, the colleges would later be much better satisfied with the students selected, the students would make better progress, fewer students would fail, and secondary schools would be given another measure of freedom from college domination. All levels of education would in time come to think more definitely in terms of accomplishment than in terms of time served.

Why not at the same time, abolish the requirement that principals recommend students to college? Some colleges do not require the recommendation, why should any? In our office we do not require that a business school stand sponsor for the success of its graduates who are employed as secretaries; we do the best job of selection possible; then we break our necks to see that those who are "admitted" do succeed. Of ccurse, we learn through experience to put much more confidence in records and letters received from some training schools than others. That is what admissions committees ought to do. All possible and pertinent factual information ought to be secured. Opinions as to possible success should be assembled including a statement from the principal or headmaster. When all materials are at hand, the admissions officer should make the decision, and no one should squawk if he makes a mistake. Nor should the college dismiss the siudent because he does not succeed well at once. Every means for wise counseling and guidance should be furnished to him, and he should be retained until the end of the year for which he has paid his fee; that is, if he attends classes, does the best he can, and is in other ways a good citizen. The writer doubts the advisability of dismissing students for low grades alone; at least not during the semester or year for which they have been admitted. In some instances the counselor should advise the student to transfer to an institution which has a program that offers greater promise of meeting his educational needs.

\section{Special Competence}

It is not expected that every college or university will look for the same knowledge and skills. Some colleges must demand competence in mathematics, others in language, or English or science. Without these abilities college success will be impossible. Achievement in these special areas will need to be examined by admissions officers of schools of engineering, business administration, dentistry, and the like, as the case may be, and these officials will need to be satisfied that accomplishments have been met before the college admits the student. It is much better to see that the requirement is met prior 
to unqualified entrance than to permit entrance on promise. It is not quite, but almost, as hazardous to admit a nonqualified student as to marry a man on promise that he will reform; in one instance out of 1,000 it does work our satisfactorily-the 999 are sources of trouble for all interested parties.

\section{Mental Ability}

In the course of securing information of all sorts and kinds, as varied as the situation warrants, in order to satisfy the criteria named above, if it is not clear that the applicant has ability, the college is justified and obligated to make rather definite use of some of the standard intelligence tests readily available. It is not a kindness to admit to a college program a person who is lacking in mental ability, even though certain collected information and opinions may seem to indicate that to date he has had a fairly good record of performance. If there is any doubt after giving one set of tests, still others should be used. The admissions officer ought to be satisfied beyond a reasonable doubt that the prospective student will succeed in the special college program to which he is being admitted, or he should not be admitted. All of this will take time and effort. But it will relieve the assistant dean or other "trouble shooter" later of much of his work and worry. In the end, time, energy, and disappointment will be saved.

\section{CONCLUSION}

A large per cent of entering freshmen should, could, and ought to continue to be admitted on the basis of their secondary-schocl record even when the above criteria are adopted. Some would be admitted solely on their highschool records, others would be admitted partially on that record, supplemented by tests and special examinations, while others would be admitted even if they had never attended high school. The chief values in the above suggested criteria are:

1. The main purpose of the secondary school would cease to be that of meeting college entrance requirements and would become that of meeting pupil needs.

2. Instead of by-passing thinking and stressing time served, both pupils and teachers would begin to think, and to think in terms of accomplishment.

3. The senior year in the secondary school would become the most studious for capable pupils instead of the least useful, as it is becoming in some schools. Those who have met the ten or twelve unit entrance requirement during the first three years, are often permitted to coast pleasantly through the senior year.

4. Colleges would gradually cease putting blame on secondary schools for the poor material being sent on to higher education. Admissions officers would be forced to develop better techniques for evaluating the qualifications of students to be admitted to their special colleges.

5. Colleges would strive harder to make students succeed. If many failed, it would be a condemnation of their ability to select.

6. Each level of education would become autonomous and a happier working relationship would be developed between secondary schools and colleges. 